\title{
Author Correction: Uncoupling of invasive bacterial mucosal immunogenicity from pathogenicity
}

\author{
Simona P. Pfister (1D), Olivier P. Schären (1D), Luca Beldi (D), Andrea Printz, Matheus D. Notter, Mohana Mukherjee (D), \\ Hai Li (D, Julien P. Limenitakis, Joel P. Werren (10, Disha Tandon, Miguelangel Cuenca, Stefanie Hagemann, \\ Stephanie S. Uster, Miguel A. Terrazos (D), Mercedes Gomez de Agüero (D), Christian M. Schürch (1), \\ Fernanda M. Coelho (1), Roy Curtiss III, Emma Slack (D), Maria L. Balmer (1) \& Siegfried Hapfelmeier (D)
}

Correction to: Nature Communications https://doi.org/10.1038/s41467-020-15891-9, published online 24 April 2020.

The original version of this Article omitted the source of genetically modified mouse strains in the Acknowledgements section. The Acknowledgements section should read: "Markus Geuking, Kathy McCoy, and Jakob Zimmermann carried out germ-free derivations of all genetically modified strains used in this study, with exception of NOD1/NOD2 knockout mice that were shared by Dana Philpott, University of Toronto, and generated by Elena Verdue and the Axenic Gnotobiotic Facility at McMaster University. We thank staff and management team of the Clean Mouse Facility, DBMR University of Bern, for gnotobiotic animal maintenance and services," This has now been corrected in both the PDF and HTML versions of the Article.

Published online: 29 January 2021

Open Access This article is licensed under a Creative Commons Attribution 4.0 International License, which permits use, sharing, adaptation, distribution and reproduction in any medium or format, as long as you give appropriate credit to the original author(s) and the source, provide a link to the Creative Commons license, and indicate if changes were made. The images or other third party material in this article are included in the article's Creative Commons license, unless indicated otherwise in a credit line to the material. If material is not included in the article's Creative Commons license and your intended use is not permitted by statutory regulation or exceeds the permitted use, you will need to obtain permission directly from the copyright holder. To view a copy of this license, visit http://creativecommons.org/licenses/by/4.0/.

(c) The Author(s) 2021 